\title{
Testing the Productivity Bias Hypothesis in Middle East Countries
}

\author{
Ferda HALICIOGLU \\ Istanbul Medeniyet University, ferda.halicioglu@medeniyet.edu.tr \\ Natalya KETENCI \\ Yeditepe University, nketenci@yeditepe.edu.tr
}

Follow this and additional works at: https://ecommons.luc.edu/meea

Part of the Business Commons

\section{Recommended Citation}

HALICIOGLU, Ferda and KETENCI, Natalya, "Testing the Productivity Bias Hypothesis in Middle East Countries". Topics in Middle Eastern and North African Economies, electronic journal, 20, 2, Middle East Economic Association and Loyola University Chicago, 2018, http://www.luc.edu/orgs/meea/

This Article is brought to you for free and open access by the Journals and Magazines at Loyola eCommons. It has been accepted for inclusion in Topics in Middle Eastern and North African Economies by an authorized administrator of Loyola eCommons. For more information, please contact ecommons@luc.edu. (c) (i) (2)

This work is licensed under a Creative Commons Attribution 3.0 License.

(C) 2018 The Authors 


\title{
Testing the Productivity Bias Hypothesis in Middle East Countries
}

\begin{abstract}
Divergence of the purchasing power parity from the equilibrium exchange rate is attributed to various factors. Productivity differentials between the countries are said to be one of the main sources, which lead to productivity bias hypothesis. The hypothesis suggests that a relatively more productive country should experience a real appreciation of its currency.

This research aims at testing the hypothesis in Middle East countries using the time series data over the period of 1970-2015 and by employing ARDL approach to cointegration. The econometric results support the hypothesis is only in the case of Bahrain, Kuwait and Saudi Arabia. This research also provides policy recommendations on the basis of empirical results.
\end{abstract}

Keywords: Productivity bias hypothesis, cointegration, Middle East countries

JEL Classifications: C22, E31, F30.

\section{Correspondence to:}

\section{Ferda HALICIOGLU}

Department of Economics, Istanbul Medeniyet University,

Kadikoy, 34700

Turkey

ferda.halicioglu@medeniyet.edu.tr

\section{Co-author}

Natalya KETENCI

Department of Economics,

Yeditepe University,

Kadikoy, 34755,

Turkey

nketenci@yeditepe.edu.tr

*An earlier version of this article was presented at the $16^{\text {th }}$ International Conference of MEEA in Ankara in 2017. 


\section{Introduction}

The Purchasing Power Parity (PPP) is the oldest theory of exchange rate determination which asserts that exchange rate between currencies of two countries is equal to the ratio of the general price level of the said countries. The validity of the PPP has been tested empirically many times and the results are not conclusive, as discussed in Bahmani-Oskooee and Nasir (2005). Divergence of the PPP from the equilibrium exchange rate is attributed to various factors. Productivity differentials between the countries are said to be one of the main sources, which lead to productivity bias hypothesis (PBH).

The PBH, which is also known as Balassa-Samuelson Hypothesis (BSH), simply suggests the appreciation of a currency in a relatively productive country. According to this hypothesis, a country with high productivity growth also experiences high wage growth, which causes a rise in prices and consequently, the real exchange rate appreciates. The origin of the hypothesis lies in the seminal works of Balassa (1964) and Samuelson (1964), where both authors independently observed that differentials of productivity growth lead to real exchange rate appreciations. Balassa (1964) advocated that due to the higher level of productivity in production of tradable goods relative to non-tradable goods (services), the exchange rate will be overvalued in terms of PPP in countries with relatively high production of tradable goods. Prices of non-tradable goods or services will be greater in countries with a higher level of productivity because of the relatively low level of productivity in the service sector. The larger gap between relative productivity gives rise to a greater gap between prices and as a consequence, deviations take place between PPPs leading to currency overvaluation. It is also noted that a more productive country is supposed to have higher standards of living, which causes higher prices of consumed goods and services. As a result, the increasing gap between prices leads to an appreciation of the more productive country's currency. Samuelson (1964) also argued that productivity differentials were a main contributing factor of overvaluation of the US dollar in the 1960s. Since then, many studies have been conducted in an attempt to test the hypothesis. 
This study aims to fill empirically the gap in the literature for the Middle East countries by employing time series data and ARDL approach to cointegration. As far as this study is concerned, the PBH has not been exclusively tested in the case of the Middle East countries. This paper is motivated further that the underlining cause of the real appreciation should be understood in depth so that the exchange rate policy can be designed accordingly. Section 2 presents a brief review of the literature. Section 3 outlines the econometric methodology. Section 4 reports the econometric results. Section 5 concludes.

\section{A Brief Literature Review}

Officer (1976) and Bahmani-Oskooee and Nasir (2005) present comprehensive reviews of empirical studies on the PBH. Officer (1976) investigated operational impact and theoretical underpinning testing the hypothesis, providing examples from the literature. He criticized the general theoretical acceptance of the hypothesis due to the lack of firm empirical evidence. Moreover, he argued that the reason that lies behind the failure to support the hypothesis in the literature is the disregard for quality difference of non-tradable goods among countries. The study of Bahmani-Oskooee and Nasir (2005) conducts the most comprehensive review of the $\mathrm{PBH}$, which categorized empirical studies on the hypothesis into three groups: cross-sectional studies, time series studies and panel studies. Bahmani-Oskooee and Nasir (2005) points out that, by and large, the cross-sectional studies fail to support the hypothesis, while most of studies of the second and third categories are in favour of the hypothesis.

Cross-Sectional Studies

Balassa (1964), who was the first to empirically test the hypothesis, found significant results by comparing ratios of PPPs to exchange rates based on 12 countries from the Organization for Economic Co-operation and Development (OECD). However, De Vries (1968) rejected the hypothesis using the sample of 64 countries. Using the data of 12 OECD and 19 Latin American countries, the study of Clauge and Tanzi (1972) did not find support for the hypothesis. Officer (1976) 
presented a new specification using the productivity differentials on a sample of 15 industrial countries and revealed significant results for the hypothesis. Clauge (1988) used the sector-specific model to evaluate the hypothesis for 19 Latin American countries and the results were in favour of it. Falvey and Gemmell (1991) extended the sector -specific models to general equilibrium framework and presented an empirical evidence for the hypothesis. The study of Bahmani-Oskoee and Niraoomand (1996), which adopted the same model as Officer (1976), failed to support the hypothesis. Bahmani-Oskooee and Nasir (2001) tested the hypothesis by pooling cross-sectional data from 68 countries over the 1960-1990 period and the results supported it.

Time Series Studies

Hsieh (1982), using the OLS (Ordinary Least Squares), displayed the first time series evidence for the hypothesis. The studies of Rogoff (1992) and Bahmani-Oskooee (1992), which both employed Engle-Granger (1987) cointegration approach, are particularly notable considering the time series properties of the variables and providing significant results for the hypothesis. Strauss (1995) employed the Johansen and Juselius multivariate cointegration approach for 14 OECD countries and lent support for the hypothesis. Using ARDL approach to cointegration to a data set of 44 countries, Bahmani-Oskooee and Nasir (2004) extended the validity of the hypothesis for 32 countries. In the last two decades, a number of time series studies presented significant empirical results for the hypothesis; see for example DeLoach (2001), Egert (2002), Bahmani-Oskooee and Gelan (2006), Drine and Rault (2008), Garcia-Solanes et al. (2008), Chowdhury (2011, 2012), Apergis (2013), Anwar and Ali (2015), Cardi and Restout (2015) and Wang et al. (2016).

\section{Panel Studies}

The first panel study on the PBH was conducted by Asea and Mendoza (1994), which used the data set of 14 OECD countries over the period of 1970-1985. The research of Asea and Mendoza (1994) used different categories of dependent and independent variables and revealed significant results for the hypothesis. The panel study of Chinn (2000), which consisted of 9 Asian-Pacific countries, supported the hypothesis. Egert et al. (2003) investigated the hypothesis by pooling quarterly data 
over the period 1995-2000 from 9 transitional countries of Central and European countries and presented significant results for the hypothesis. Bahmani-Oskooee and Miteza (2004) applied the panel cointegration approach of Pedroni for the data of 61 countries and found support for the hypothesis for the entire panel, as well as sub-groups of countries. Genius and Tzouvelekas (2008) allowed country specific estimations in a panel study for 59 industrialized and developing countries and refuted the hypothesis in the case of most African and Latin American countries but supported it in the majority of the developed countries. Irandoust (2017) employed panel VAR cointegration technique to 8 trading partners of New Zealand, concluding it with significant results. The research of Iyke and Odhiambo (2017) implemented the GMM (Generalized Method of Moments) technique in search of validating the hypothesis for 8 middle-income countries in Africa over the period 1960-2009 and extended its support for the hypothesis.

It is evident that empirical results may vary with the econometric techniques, data quality, model specification and data span.

\section{Model and Econometric Methodology}

This study adopts the model of Officer (1976), hence we form the following long-run relationship between real exchange rates and productivity differentials, in double logarithmic linear form as:

$R E R_{t}=a_{0}+a_{1} P R O D_{t}+\varepsilon_{t}$

where $R E R_{t}$ is real exchange rates, expressed as $\left(P_{i} / P_{U S}\right) E X$ in which $P_{i}\left(P_{U S}\right)$ is the price level in country $i(\mathrm{US})$. EX is the equilibrium exchange rates defined as number of $i$ 's currency per unit of dollar. $P R O D_{t}$ refers to the productivity differentials defined as $P R O D_{i} / P R O D_{U S}$. Thus, the productivity of country in $i$ is $P R O D_{i}$ and $P R O D_{U S}$ is the productivity in US. $\varepsilon_{t}$ is the classical error term. $t$ stands for time period. Equation (1) postulates that if a more productive country is to experience a real appreciation of its currency in the long-run, it is expected that the slope parameter, $a_{1}$ should be positive. 
The long-run relation in Eq. (1) should incorporate the short-run dynamic adjustment process in order to provide insights of adjustments between time periods. To this extent, Engle-Granger (1987) cointegration approach can be utilized in the first instance. Then, Eq. (1) becomes as follows:

$\Delta R E R_{t, j}=b_{0}+\sum_{i=1}^{p} b_{1 i} \Delta R E R_{t-i}+\sum_{i=0}^{q} b_{2 i} \Delta P R O D_{t-i}+\gamma \varepsilon_{t-1}+\mu_{t}$

where $\Delta$ represents change, $\gamma$ is the speed of adjustment parameter and $\varepsilon_{t-1}$ is the one period lagged error correction term, which is estimated from the residuals of Eq. (1). The Engle-Granger cointegration method requires all variables in Eq. (1) are integrated of order one, $I(1)$ and the error term is integrated order of zero, $I(0)$ for establishing a cointegration relationship. This strict condition of the order of integration seems difficult to be fulfilled in many time series data. Therefore, an alternative and powerful single cointegration technique was proposed by Pesaran et al. (2001) which is also known as autoregressive-distributed lag (ARDL). Pesaran et al. (2001) approach combines Engle-Granger (1987) two steps into one by replacing $\varepsilon_{t-1}$ in Eq. (2) with its equivalent from Eq. (1). $\varepsilon_{t-1}$ is substituted by linear combination of the lagged variables as in Eq. (3).

$$
\Delta R E R_{t, j}=c_{0}+\sum_{i=1}^{m 1} c_{1 i} \Delta R E R_{t-i}+\sum_{i=0}^{m 2} c_{2 i} \Delta P R O D_{t-i}+c_{3} R E R_{t-1}+c_{4} P R O D_{t-1}+v_{t}
$$

To obtain Eq. (3), one has to solve Eq. (1) for $\varepsilon_{t}$ and lag the solution equation by one period. Then this solution is substituted for $\varepsilon_{t-1}$ in Eq. (2) to arrive at Eq. (3). Eq. (3) is a representation of the ARDL approach to cointegration ${ }^{1}$.

\footnotetext{
1 Different applications of the ARDL approach to cointegration can be found in the following studies: Bahmani et al. (2017), Bahmani et al. (2016), Uslu, et al. (2016), Halicioglu and Ketenci (2016), Durmaz (2015), Tayebi (2014), Halicioglu and Karatas (2013), Halicioglu (2013), Pattichis (2012), Catik et al. (2011), Andres and Halicioglu (2011), Dell'Anno and Halicioglu (2010), Halicioglu (2007).
} 
Eq. (3) is estimated using an appropriate lag selection criterion after a long-run relationship has been established. At the second step of the ARDL cointegration procedure, the ARDL approach to cointegration also provides the error correction representation model (ECM) of Eq. (1) which presents the speed of adjustment between the dependent variable and independent variables. In order to obtain the ECM representation, the lagged level variables in Eq. (3) are replaced by $E C_{t-1}$ as in Eq. (4):

$\Delta R E R_{t, j}=d_{0}+\sum_{i=1}^{n 1} d_{1 i} \Delta R E R_{t-i}+\sum_{i=0}^{n 2} d_{2 i} \Delta P R O D_{t-i}+\lambda E C_{t-1}+\omega_{t}$

A negative and statistically significant estimation of $\lambda$ not only represents the speed of adjustment but also provides an alternative means of supporting cointegration between the variables.

Pesaran et al. (2001) cointegration approach has some methodological advantages in comparison to other single cointegration procedures such as: the ARDL approach to cointegration tests the existence of a long-run relationship between the variables regardless of whether the underlying regressors are purely stationary $I(0)$, purely non-stationary $I(1)$, or mutually cointegrated and the small sample properties of the bounds testing approach are far superior to that of multivariate cointegration, as proved in Narayan (2005).

The ARDL cointegration approach involves two steps for estimating the long run relationship. The bounds testing procedure is based on a Wald type (F-statistics) which is also the first step of the ARDL cointegration method. Accordingly, a joint significance test that implies no cointegration under the null hypothesis, $\left(\mathrm{H}_{0}\right.$ : $\left.c_{3}=c_{4}=0\right)$, against the alternative hypothesis, $\left(\mathrm{H}_{1}\right.$ : at least one $c_{3}$ to $\left.c_{4} \neq 0\right)$ should be performed for Eq. (3). The F test used for this procedure has a non-standard distribution. Thus, Pesaran et al. (2001) computed two sets of asymptotic critical values for testing cointegration for a given significance level with and without a time trend. One set assumes that all variables are $I(0)$ and the other set assumes that they 
are all $I(1)$. If the computed F-statistic exceeds the upper bound critical value, then the null hypothesis of no cointegration can be rejected. Conversely, if the F-statistic falls below the lower bound critical value, the null hypothesis cannot be rejected. Lastly, if the F-statistic falls between these two sets of critical values, the result is inconclusive.

W- testing procedures in the Pesaran et al. (2001) approach are considered to be pre-testing for cointegration. Moreover, this stage of testing is very sensitive to lag selection criterion and lag lengths. As a consequence, it is quite likely that the establishment of a cointegration relationship may fail due to wrong selection criterion or selected lag length. To overcome this possible shortcoming, we follow Kremers et al. (1992) and Banerjee et al. (1998) who proved that a negative and significant $\mathrm{EC}_{\mathrm{t}-1}$ could be used as an alternative evidence of cointegration if the Engle-Granger (1987) approach fails to establish a cointegration relationship among the variables. Therefore, this study will also utilize the results from the error correction model to establish the existence of cointegration should the pre-testing stage of Pesaran et al. (2001) fail to do so.

\section{Empirical Results}

Eq. (3) was estimated for 17 Middle East countries using selected annual data over the period 1970-2015. The data period for each country along with variable definitions and data sources are presented in Appendix.

Unit root testing from different procedures and graphical inspections of the variables prove that the variables in econometric estimations are all stationary either in level or first differenced forms ${ }^{2}$. In order to present the sensitivity of the lag length selection for the F-testing procedure, an initial lag of 2 was imposed on each differenced variable in Eq. (3). Then, the lag length of 3 and 4 were also examined on the differenced variables using AIC (Akaike Information Criterion) to select the optimum number of lags. The results from the bounds F-test are reported

\footnotetext{
${ }^{2}$ The results of unit root tests are available on request.
} 
in Table 1. Table 1 demonstrates that F-statistics are indeed sensitive to the selected lag length. However, there is no consistent pattern in the statistics since they seem to go in either direction of increase or decrease. The results in Table 1 display that the calculated F statistic is greater than its upper bound critical value only in the case of Bahrain, Oman, Qatar, and Saudi Arabia. In other cases, where the F statistic reject cointegration, a negative and significant $E C_{t-1}$ is considered to be an alternative way of supporting cointegration. As far as the latter approach suggests, there exists evidence of cointegration in the case of Egypt, Kuwait, UAE, and Yemen. However, in the latter case, the slope estimates of Egypt, UAE and Yemen appear to be negative, indicating that the PBH does not hold for them. In the case of Kuwait, it is seen that the estimated slope coefficient is statistically significant and is greater than zero which validates the PBH.

[Insert Table 1 About Here] 


\begin{tabular}{|c|c|c|c|c|c|}
\hline & \multicolumn{3}{|c|}{ F-statistic } & \multirow{2}{*}{$\begin{array}{l}\text { t-ratio } \\
\text { for } E C_{t-1}\end{array}$} & \multirow{2}{*}{$\begin{array}{l}\text { Coefficient estimate } \\
\text { of slope parameter }\end{array}$} \\
\hline & 2 lags & 3 lags & 4 lags & & \\
\hline Algeria & 3.30 & 3.56 & 3.18 & 2.52 & $1.61 \quad(6.41)^{*}$ \\
\hline Bahrain & $9.70^{* *}$ & 5.25 & 2.49 & $4.06^{* *}$ & $0.73 \quad(4.67)^{*}$ \\
\hline Egypt & 4.48 & 4.37 & 4.34 & $3.02^{* *}$ & $-0.57 \quad(0.94)$ \\
\hline Iran & 2.63 & 2.60 & 2.50 & 2.24 & $0.75 \quad(0.83)$ \\
\hline Iraq & 1.25 & 1.21 & 1.17 & 1.45 & $7.28 \quad(0.73)$ \\
\hline Jordan & 3.29 & 1.54 & 1.52 & 1.82 & $(0.48)^{*}$ \\
\hline Kuwait & 6.09 & 3.53 & 2.75 & $3.36^{* *}$ & $0.08 \quad(1.94)^{* * *}$ \\
\hline Lebanon & 0.64 & 1.13 & 2.19 & 0.90 & $-8.69(0.43)$ \\
\hline Morocco & 2.01 & 2.20 & 2.44 & 2.09 & $(0.03)$ \\
\hline Oman & $35.8^{*}$ & $13.1^{*}$ & 6.03 & $8.06^{*}$ & $-0.33 \quad(1.26)$ \\
\hline Qatar & $36.5^{*}$ & $20.4^{*}$ & $8.58^{* *}$ & 1.96 & $(1.25)$ \\
\hline Saudi & $22.8^{*}$ & $20.5^{*}$ & $13.9^{*}$ & $6.76^{*}$ & $(14.4)^{*}$ \\
\hline Arabia & & & & & \\
\hline Syria & 2.71 & 2.76 & 3.70 & 2.34 & $-2.51 \quad(4.07)^{*}$ \\
\hline Tunisia & 5.35 & 4.68 & 3.55 & 1.88 & $-6.32(1.94)^{* * *}$ \\
\hline Turkey & 1.33 & 1.86 & 2.81 & 1.70 & $2.22 \quad(1.20)$ \\
\hline UAE & $30.1^{*}$ & $41.7^{*}$ & $65.7^{*}$ & $7.54^{*}$ & $-0.21(3.28)^{* *}$ \\
\hline Yemen & 2.60 & 3.01 & 5.43 & $2.99 * * *$ & $-1.05(1.25)$ \\
\hline
\end{tabular}

\section{Notes:}

a. ${ }^{*}{ }^{* *}$ and ${ }^{* * *}$ indicate, $1 \%, 5 \%$ and $10 \%$ statistical significance levels, respectively. t-ratios for coefficient estimate of slope parameter are presented in parentheses.

b. The upper bound critical value of the F-test for cointegration when there is one exogenous variable is $9.78,7.42$ and 6.33 at the $1 \%, 5 \%$ and level of statistical significance levels, respectively. These come from Pesaran et al. (2001, Table CI, Case III, p. 300).

c. The critical value for significance of $\mathrm{ECM}_{\mathrm{t}-1}$ with one explanatory variable is $-3.94,-3.28$ and 2.93 at the $1 \%, 5 \%$ and $10 \%$ statistical significance levels, respectively. These come from Benarjee et al. (1998, Table I, with sample size less than 50. p. 276).

Regarding the results of the ARDL approach to cointegration, the long-run slope estimates of Bahrain and Saudi Arabia are positive and statistically significant, suggesting the existence of the PBH. However, the slope estimates of Oman and Qatar are statistically insignificant, indicating that we cannot draw any statistical inferences on these countries. Hence, we eliminate these countries from further analysis. These results demonstrate that there is only partial support of the hypothesis in the Middle East countries since only 3 out of 17 estimates display statistically significant and positive values of the long-run slope parameters. Within 
these three countries, the impact of the PHB is the strongest in the case of Bahrain, showing that $1 \%$ rise in the relative productivity leads to $0.73 \%$ appreciation in real exchange rates.

Table 2 presents the order of ARDL procedures, value of lagged error correction terms, some standard regression diagnostics such as autocorrelation, functional form, heteroscedasticity, normality and summary results of the overall residual stability tests.

It appears from the results in Table 2 that the diagnostic tests of Bahrain, Kuwait, and Saudi Arabia are also statistically satisfactory which support the reliability of the econometric results. Regarding the lagged error correction terms with significant PBH in Table 2, Saudi Arabia has the highest lagged error-correction term of -0.24 which suggests that any disequilibrium between the currencies of USA and Saudi Arabia will be eliminated within around four years.

[Insert Table 2 About Here] 
This research tested the validity of the PBH for 17 Middle East countries using the ARDL approach to cointegration. The econometric results from this research reveal that the PBH is being validated in the case of only 3 Middle East countries, namely Bahrain, Kuwait and Saudi Arabia.

We suspect the failure of the $\mathrm{PBH}$ in the rest of Middle East countries may be attributed to some macroeconomics factors such as the impact of globalization and free trade movements that many developing countries have been experiencing, in addition to the consequences of various government policies in the form trade, exchange rate and development, which have not been included in our study.

As far as the policy recommendations are concerned, it is crystal clear that the countries should develop economic policies that would lead to a rise in productivity, especially in the sectors of tradable and non-tradable goods in order to gain international competitive advantage in real exchange rates in the long-run. Those policies should be very comprehensive and sustainable so that the gains from them would last for a long time. Macroeconomic policies aiming at increasing productivity may range from different simple tax incentives to sophisticated education of labour force. To this end, for example, the quality of labour in the sector of tradable goods plays a crucial role for raising international competitiveness. Improving the labour quality with education will also increase the productivity of this production factor. Similarly, research and development expenditures may be utilized specifically to increase the productivity of production factors of capital and technology. 


\section{References}

Andres, A.R. and Halicioglu, F. (2011), "Testing the hypothesis of the natural suicide rates: further evidence from OECD data", Economic Modelling, Vol.28, Nos: 1-2, pp.22-26.

Anwar, S. and Ali, S.Z. (2015), "Productivity bias hypothesis: evidence from South Asia”, Applied Economics Letters, Vol.22, No.17, pp.1389-1394.

Asea, P.K. and Mendoza, E.G. (1994), "Balassa-Samuelson model: an overview", Review of International Economics, Vol.2, No.3, pp.191-200.

Apergis, N. (2013), "The domestic Balassa-Samuelson effect of inflation for the Greek economy", Applied Economics, Vol.45, pp.3288-3294.

Bahmani-Oskooee, M. (1992), "A time-series approach to test the productivity bias hypothesis in purchasing power parity”, Kyklos, Vol.45, No.2, pp.227-236.

Bahmani-Oskooee, M., Halicioglu, F. and Bahmani, S. (2017), "Do exchange rate changes have symmetric or asymmetric effects on the demand for money in Turkey ?", Applied Economics, Vol.49, No.42, pp.4261-4270.

Bahmani-Oskooee, M., Halicioglu, F. and Hegerty, S.W. (2016), "Mexican bilateral trade and the J-curve: an application of the nonlinear ARDL model", Economic Analysis and Policy, Vol.50, pp.23-40.

Bahmani-Oskooee, M. and Gelan, A. (2006), "Black market exchange rate and the productivity bias hypothesis”, Economics Letters, Vol.9, No.2, pp.243-249.

Bahmani-Oskooee, M. and Nasir, A.B.M. (2005), "Productivity bias hypothesis and the purchasing power parity: A review article", Journal of Economic Surveys, Vol.19, No.4, pp. 671-696.

Bahmani-Oskooee, M. and Nasir, A.B.M. (2004), "ARDL approach to test the productivity bias hypothesis", Review of Development Economics, Vol.8, No.3, pp.483-468.

Bahmani-Oskooee, M. and Miteza, I. (2004), "Panel cointegration and productivity bias hypothesis", Journal of Economic Studies, Vol.31, No.5, pp.448-456.

Bahmani-Oskooee, M. and Nasir, A.B.M. (2001), "Panel data and productivity bias hypothesis", Economic Development and Cultural Change, Vol.49, pp.393-402.

Bahmani-Oskooee, M. and Niraoomand, F. (1996), "A re-examination of Balassa's productivity bias hypothesis", Economic Development and Cultural Change, Vol.45, No.4, pp.195-204. 
Balassa, B. (1964), "The purchasing power parity doctrine: a reappraisal”, Journal of Political Economy, Vol.72, pp.584- 96.

Banerjee, A., Dolado, J.J. and Mestre, R. (1998), "Error-correction mechanism tests For cointegration in a single equation framework", Journal of Time Series Analysis, Vol.19, pp.267-283.

Brown, R.L., Durbin, J. and Evans, J.M. (1975), "Techniques for testing the constancy of regression relations over time", Journal of the Royal Statistical Society, Vol.37, No.1, pp.149-163.

Catik, A.N., Martin, C. and Onder, A.O. (2011), "Relative price variability and the Phillips curve: evidence from Turkey", Journal of Economic Studies, Vol.38, No.5, pp.546-561.

Cardi, O. and Restour, R. (2015), "Imperfect mobility of labor across sectors: a reappraisal of the Balassa-Samuelson effect", Journal of International Economics, Vol. 97, No.2, 249-265.

Chinn, M.D. (2000), "The usual suspects? Productivity and demand shocks and AsiaPacific real exchange rates", Review of International Economics, Vol.8, pp.20-43.

Chowdhury, K. (2011), "Modelling the Balassa-Samuelson effect in Australia", Australasian Accounting, Business and Finance Journal, Vol.5, No.1, pp.77-91.

Chowdhury, K. (2012) "The real exchange rate and the Balassa-Samuelson hypothesis in SAARC countries: an appraisal", Journal of the Asia Pacific Economy. Vol.17, No.1, pp.52-73.

Clauge, C.K. (1988), "Purchasing power parities and exchange rates in Latin America”, Economic Development and Cultural Change, Vol.36, pp.529-541.

Clauge, C.K. and Tanzi, V. (1972), "Human capital, natural resources and the purchasing power parity doctrine: some empirical results", Economia Internazionale, Vol.25, pp.3-18.

DeLoach, S.B. (2001), "More evidence in favor of the Balassa-Samuelson hypothesis", Review of International Economics, Vol.9, No.2, pp.336-342.

Dell'Anno, R. and Halicioglu, F. (2010), "An ARDL Model of Recorded and Unrecorded Economies in Turkey", Journal of Economic Studies, Vol. 37, No.6, pp.627-646.

De Vries, M.G. (1968), "Exchange rate depreciation in developing countries", IMF Staff Papers, Vol.15, pp.560-578. 
Durmaz, N. (2015), "Industry level J-curve in Turkey", Journal of Economic Studies, Vol.42, No.4, pp.689-706.

Drine, I. and Rault, C. (2004), "Does the Balassa-Samuelson hypothesis hold for Asian countries? An empirical analysis using panel data and cointegration tests", Applied Econometrics and International Development, Vol.4, No.4, pp.59-84.

Egert, B. (2002), "Does the productivity-bias hypothesis hold in the transition Countries: Evidence from five CEE economies in the 1990s", Eastern European Economies, Vol.40, No.2, pp.5-37.

Egert, B., Drine, I., Lommatzsch, K., and Rault, C. (2003), "The Balassa-Samuelson effect in Central and Eastern Europe: Myth or reality?", Journal of Comparative Economics, Vol.31, No.3, pp.552-572.

Engle, R.F. and Granger C.W.J. (1987), “Cointegration and error correction: representation, estimation, and testing”. Econometrica, Vol.55, pp.251-276.

Falvey, R.E., Gemmell, N. (1991), “Explaining service-price differences in international comparisons”, American Economic Review, Vol.81, pp.1295-1309.

Garcia-Solanes, J., Sancho-Portero, F.I., and Torrejon-Flores, F. (2008), "Beyond the Balassa-Samuelson effect in some new member states on the European Union", Economic Systems, Vol.32, pp.17-32.

Genius, M. and Tzouvelekas, V. (2008), The Balassa-Samuelson productivity bias hypothesis: Further evidence using panel data. Agricultural Economic Review, Vol.9, No.2, pp.31-41.

Halicioglu, F. and Ketenci, N. (2016), "The impact of international trade on environmental quality: the case of transition countries", Energy, Vol.109, pp.11301138.

Halicioglu, F. (2013), "Dynamics of obesity in Finland”, Journal of Economic Studies, Vol.40, No.5, pp.644-657.

Halicioglu, F. and Karatas, C. (2013), "A social discount rate for Turkey", Quality and Quantity, Vol.47, No.2, pp.1085-1091.

Halicioglu, F. (2012) "Temporal Causality and Dynamics of Crime in Turkey" International Journal of Social Economics, Vol. 39, No.9, pp.704-720.

Halicioglu, F. (2007): "The J-curve Dynamics of Turkish Bilateral Trade: A Cointegration Approach", Journal of Economic Studies, 34(2), 103-119. 
Halicioglu, F. (2004) "The Gibson Paradox: An Empirical Investigation for Turkey" European Research Studies, Vol.7, Nos: 1-2, pp.111-119.

Halicioglu, F. (2001) “An Econometric Analysis of Foreign Direct Investment Flows into Turkey from Major Global Regions: 1975-1999"

Conference Paper, presented at METU International Conference in Economics V, Ankara.

Halicioglu, F. (1999) "The Black Economy in Turkey: An Empirical Investigation” The Review of Political Sciences of Ankara University, Vol.53, No.1, pp.147-158.

Hsieh, D.A. (1982), "The determination of the real exchange rate: the productivity approach", Journal of International Economics, Vol.12, pp.355-362.

Irandoust, M. (2017), "Symmetry, proportionality and productivity bias hypothesis: evidence from panel-VAR models", Economic Change and Restructuring, Vol.50, pp.79-93.

Iyke, B. N. and Odhiambo, N.M. (2017), "An empirical test of the Balassa-Samuelson hypothesis: evidence from eight middle-income countries in Africa", Economic Systems, Vol.41, No.2, pp.297-304.

Kremers, J.M., Ericsson, N.R., and Dolado, J.J. (1992), "The power of cointegration tests", Oxford Bulletin of Economic Statistics, Vol.54, pp.325-348.

Narayan, P.K. (2005), "The saving and investment nexus for China: evidence from cointegration tests", Applied Economics, Vol.37, pp.1979-1990.

Officer, L.H. (1976), “The productivity bias in purchasing power parity: An econometric investigation", International Monetary Fund Staff Papers, Vol.23, pp.545-579.

Pattichis, C. (2012), "Exchange rate effects on trade in services", Journal of Economic Studies, Vol. 39, No.6, pp.697-708.

Pesaran, H.M., Shin, Y., and Smith, J.R. (2001) "Bounds testing approaches to the analysis of relationships". Journal of Applied Econometrics, Vol.16, pp.289-326.

Rogoff, K. (1992), "Traded goods consumption smoothing and the random walk behavior of the real exchange rates", Bank of Japan Monetary and Economic Studies, Vol.10, No.2, pp.1-29.

Samuelson, P. A. (1964), "Theoretical notes on trade problems", Review of Economics and Statistics, Vol.46, pp.145-154. 
Strauss, J. (1995) "Real exchange rates, PPP and the relative prices of nontraded goods", Southern Economic Journal, Vol.61, No.4, pp.991-1005.

Tayebi, S.K. and Yazdani, M. (2014) "Financial crisis, oil shock and trade in Asia", Journal of Economic Studies, Vol.41, No.4, pp.601-614.

Uslu, C., Aydogan, E.T., and Ketenci, N. (2016) "Impact of structural breaks presence on economic development of emerging countries", CEA Journal of Economics, Vol.11, No.2, pp.5-21.

Wang, W., Xue, J., and Du, C. (2016) "The Balassa-Samuelson hypothesis in the developed and developing countries revisited", Economics Letters, Vol.146, pp.3338.

\section{Appendix}

Data Sources and Variable Definitions

All data come from World Development Indicators of the World Bank (WB).

Annual data span (1970-2015) is used for all countries apart from Yemen (19902015).

\section{Variables}

$R E R$ is the natural logarithm of real exchange rate which is defined as $R E R=\left(\left(P_{i} / P_{U S}\right) \times E X\right)$ in which nominator and denominator are represented by home country's and US's Consumer Price Indexes (CPI) and EX is nominal exchange rate, which is defined amount of dollars per country i's currency. Source: WB

$P R O D$ is the ratio of $P R O D_{i} / P R O D_{U S}$ refers to the natural logarithm of productivity differentials between home country and USA. Productivity is measured by per capita which is defined as the ratio of real GDP over total employment for home country and USA, respectively. Source: WBI. 